\title{
QUANTITATIVE VARIATION OF RIBOSOMAL RNA GENES IN FLAX GENOTROPHS
}

\author{
CHRISTOPHER A. CULLIS \\ John Innes Institute, Colney Lane, Norwich NR4 7UH
}

Received: 11.x.78

\begin{abstract}
SUMmary
The variation in the proportion of the DNA coding for ribosomal RNA in three flax genotrophs, and the inheritance of this proportion in crosses between them were determined. DNA variation was observed and lines could be selected from within a genotroph with differing proportions of rDNA. The degree of variation increased when the genotrophs were crossed, the extent of the increase being dependent on the particular genotrophs involved in the cross. The variation extended into the F2 and F3 generations. The mean values of F2 and F3 families were not highly correlated with the value of the parental plant from which they were derived. In one cross the F2 and F3 means were close to the average value of the two parents involved in the original cross. In the other cross, the F1, F2 and F3 means were all less than the average value of the two original parents.
\end{abstract}

\section{IntroduGtion}

Hertable changes can be induced in some flax varieties when they are grown in certain environments (Durrant, 1962a, 1971). The initial observation was that stable forms differing in plant weight (large, $\mathrm{L}$ and small, S genotrophs) were produced in subsequent generations following the growth of the original variety (plastic, $\mathrm{Pl}$ ) in particular environments. The two stable genotrophs then behaved as genetically distinct lines in most aspects.

In addition to the difference in plant weight, the two stable genotrophs differed from each other and $\mathrm{Pl}$ in a number of properties. L was taller than $\mathrm{S}$ but shorter than Pl. L had 16 per cent more nuclear DNA than S with Pl having an intermediate amount (Evans, Durrant and Rees, 1966). PI and S have hairy septa of the seed capsule while $L$ has hairless septa (Durrant and Nicholas, 1970). L and Pl have been shown to have similar numbers of ribosomal RNA cistrons while $\mathrm{S}$ has a reduced number (Timmis and Ingle, 1973, 1975; Cullis, 1975, 1976). The isozyme band pattern of peroxidase and acid phosphatase has been shown to be different between $\mathrm{L}, \mathrm{S}$ and $\mathrm{Pl}$ (Gullis and Kolodynska, 1975).

Under certain circumstances the induced changes in the genotrophs have been shown to be unstable (Durrant and Jones, 1971; Joarder, Al-Saheal, Begum and Durrant, 1975). As a result of this, lines have been produced which were no longer identical to any of the L, S or Pl genotrophs. In particular a small genotroph was formed which had 30 per cent fewer ribosomal RNA cistrons than any of the other small genotrophs (Cullis, 1976).

The hybrids between $\mathrm{L}$ and $\mathrm{S}$ genotrophs appeared to be genetically unstable for certain characters. For plant weight the Fl of such a cross showed increased variation and a similar phenomenon was observed among 
the F2 families (Durrant, 1962b). Instability was also observed for the capsule septa hair number in crosses between L and S (Durrant and Nicholas, 1970; McLellan and Durrant, 1973). However, the isozyme band pattern for peroxidase showed dominance for the $\mathrm{L}$ pattern in the $\mathrm{F} 1$ in crosses between $\mathrm{L}$ and $\mathrm{S}$ and segregated approximately $3: 1, \mathrm{~L}: \mathrm{S}$ type in the F2 (Cullis, 1977).

A model to account for the observed events in the induction of environmental changes in flax has been proposed (Cullis, 1977). One of the predictions made from this model was that there should be changes in the number of copies of particular DNA sequences in the hybrid nucleus formed by crossing genotrophs. If the ribosomal RNA genes are affected, then variation for these genes should be observed in crosses between genotrophs. In this study the inheritance of the amount of DNA coding for ribosomal RNA (rDNA) was determined in crosses between three genotrophs with differing rDNA amounts. The genotrophs used were $\mathrm{L}$ and $\mathrm{S}$, the large and small types originally induced by Durrant (Durrant, 1962a) and $\mathrm{L}_{6}$, a line which was derived from $L$ but which has plant weight and height similar to $S$. The aim was to determine whether or not there was variability in the rDNA amount and, if variability was observed, whether or not the extent of the variability was dependent on the particular genotrophs involved in the crosses.

\section{MAterials AND methods}

\section{(i) Plant material}

The genotrophs $\mathrm{L}, \mathrm{S}$ and $\mathrm{L}_{6}$ have been described elsewhere (Cullis, 1976, 1977). Plants were grown singly in pots in a controlled environment cabinet at $20^{\circ} \mathrm{C}$ with a 16 hour $/ 8$ hour, light/dark cycle. Crosses were made between plants with the particular pollen parent plant noted in each case. The genotrophs have been inbred for a large number of generations (at least 11 generations for $\mathrm{L}$ and $\mathrm{S}$, and eight generations for $\mathrm{L}_{6}$ ).

\section{(ii) $D \mathcal{N} A$ preparation}

Total DNA was prepared from leaves by grinding in $3 \times \mathrm{SSC}, 0 \cdot 1 \mathrm{M}$ EDTA, $p \mathrm{H} 8 \cdot 0,0 \cdot 1 \mathrm{~m}$ Na-diethyldithiocarbamate $(2 \mathrm{ml} / \mathrm{g}$ tissue $)$ and then adding sodium lauryl sulphate to $l$ per cent $(w / v)$. The mixture was shaken with an equal volume of chloroform-isoamyl alcohol $(24: 1, \mathrm{v} / \mathrm{v})$ for 10 minutes. The aqueous layer was removed after centrifugation at $2500 \mathrm{~g}$ for 10 minutes and the DNA spooled following the addition of two volumes of ethanol. The precipitate was redissolved in $0 \cdot 1 \times \mathrm{SSC}$ (SSG: $0 \cdot 15 \mathrm{M}-\mathrm{NaCl}, 0 \cdot 015 \mathrm{~m}$-trisodium citrate, $p \mathrm{H} 7 \cdot 2$ ) and the solution made up to $1 \times \mathrm{SSC}$. The DNA was purified by digestion of the preparation by deoxyribonuclease-free RNase $(50 \mu \mathrm{g} / \mathrm{ml})$ and $\alpha$-amylase $(50 \mu \mathrm{g} / \mathrm{ml})$ for 30 minutes at $37^{\circ} \mathrm{C}$, followed by digestion with pronase $(1 \mathrm{mg} / \mathrm{ml})$ for 1 hour. The mixture was then deproteinised with chloroform-isoamyl alcohol and the DNA precipitated from the aqueous layer with two volumes of ethanol. Prior to hybridisation the DNA was purified by preparative CsCl centrifugation. Approximately $200 \mu \mathrm{g}$ DNA was centrifuged to equilibrium in CsCl (density $1.700 \mathrm{~g} \mathrm{~cm}^{-3}$ ) at 40,000 r.p.m. for 44 hours at $25^{\circ}$ in a Beckman 50 rotor. 


\section{(iii) Preparation and fractionation of labelled $R \mathcal{N A}$}

Peas were surface sterilised and germinated under sterile conditions for 72 hours. The roots of the intact plants were then immersed in water containing $200 \mu \mathrm{Ci} / \mathrm{ml}{ }^{3} \mathrm{H}$-uridine for a further 72 hours. The root tips were cut off and homogenised in $30 \mathrm{~mm}$-Tris, $p \mathrm{H} 9.9,0.15 \mathrm{M}-\mathrm{NaCl}, 0.5$ per cent sarcosyl. The mixture was deproteinised with an equal volume of phenol/ cresol $(500 \mathrm{~g}$ phenol, $70 \mathrm{ml} \mathrm{m}$-cresol, $0.5 \mathrm{~g}$ 8-hydroxyquinoline, $55 \mathrm{ml}$ water) and the nucleic acids precipitated with 95 per cent ethanol containing $0 \cdot 1 \mathrm{~m}$-sodium acetate, $p \mathrm{H} 5 \cdot 5$. The RNA was fractionated on 2.4 per cent polyacrylamide gels and the regions containing the two large ribosomal RNAs were sliced out and extracted separately with a medium containing $3 \mathrm{ml} 0.15 \mathrm{M}-\mathrm{NaCl}, 0.1 \mathrm{ml} 10$ per cent sodium lauryl sulphate, $0.1 \mathrm{ml}$ bentonite $(40-50 \mathrm{mg} / \mathrm{ml})$ and $3 \mathrm{ml}$ phenol/cresol solution. After centrifugation at $3000 \mathrm{~g}$ for 10 minutes the aqueous layer was removed, extracted with ether and then used for hybridisation.

The specific activities (cpm/ $\mathrm{g}$ RNA) of the RNA preparations used were : 10,000, 10,700, 11,500 and 12,400.

\section{(iv) Hybridisation}

DNA dissolved in $0.1 \times \mathrm{SSC}$ at $30-50 \mu \mathrm{g} / \mathrm{ml}$ was denatured by the addition of $0 \cdot 1$ volume of $1 \mathrm{~N}-\mathrm{NaOH}$. After 15 minutes at room temperature the solution was neutralised by the addition of $0 \cdot 1$ volume of $1 \mathrm{~N}-\mathrm{HCl}$ and the salt concentration increased by the addition of 0.4 volume of $24 \times \mathrm{SSC}$. The denatured DNA was loaded on to a $13 \mathrm{~mm}$ HAWP millipore filter (14-22 $\mu \mathrm{g}$ DNA/filter). The filter was air dried and finally dried in an oven at $80^{\circ} \mathrm{C}$ for 2 hours before use. The DNA filters were incubated separately with the labelled RNA in $6 \times \mathrm{SSC}$ at $70^{\circ} \mathrm{C}$ for 4 hours in a volume of $1 \mathrm{ml}$, removed from the RNA and washed successively in $6 \times \mathrm{SSC}$, three changes of $2 \times \mathrm{SSC}$ containing RNAse $(10 \mu \mathrm{g} / \mathrm{ml})$, and then dried at $80^{\circ} \mathrm{C}$. The radioactivity bound was determined by scintillation counting with 2,4diphenyloxazole ( $4 \mathrm{~g} /$ litre $)+1,4$-di[2-(5-phenyloxazole)benzene] $(0 \cdot 25 \mathrm{~g} /$ litre) in toluene. After counting, the DNA content of the filters was determined by acid hydrolysis (Brown and Weber, 1968). Duplicate filters of each DNA were incubated in each experiment and all measurements were corrected for the background of filters lacking DNA, but which had been taken through all the stages of the hybridisation procedure. In the hybridisation reaction a 2 : 1 mixture of the $1.3 \times 10^{6}$ daltons and $0.7 \times 10^{6}$ daltons $\mathrm{rRNAs}$ at $5 \mu \mathrm{g} / \mathrm{ml}$ was used as this had previously been shown to be above the saturation value (Cullis, 1976). The results have been expressed as per cent RNA/DNA hybridisation and no correction has been made for any differences in the DNA amount per cell which may have existed between lines.

\section{RESUlts}

(i) Variation in the proportion of $r D \mathcal{N} A$ in $L, S$ and $L_{6}$ genotrophs

The proportion of rDNA of $\mathrm{L}, \mathrm{S}$ and $\mathrm{L}_{6}$ has been shown to be different (Cullis, 1976). The proportion of rDNA in the DNA extracted from single plants is shown in figs. $1 \mathrm{a}, \mathrm{b}$ and $2 \mathrm{a}, \mathrm{b}$. These plants were grown from seed from the same plant as that used to generate the crosses also shown in figs. 1 


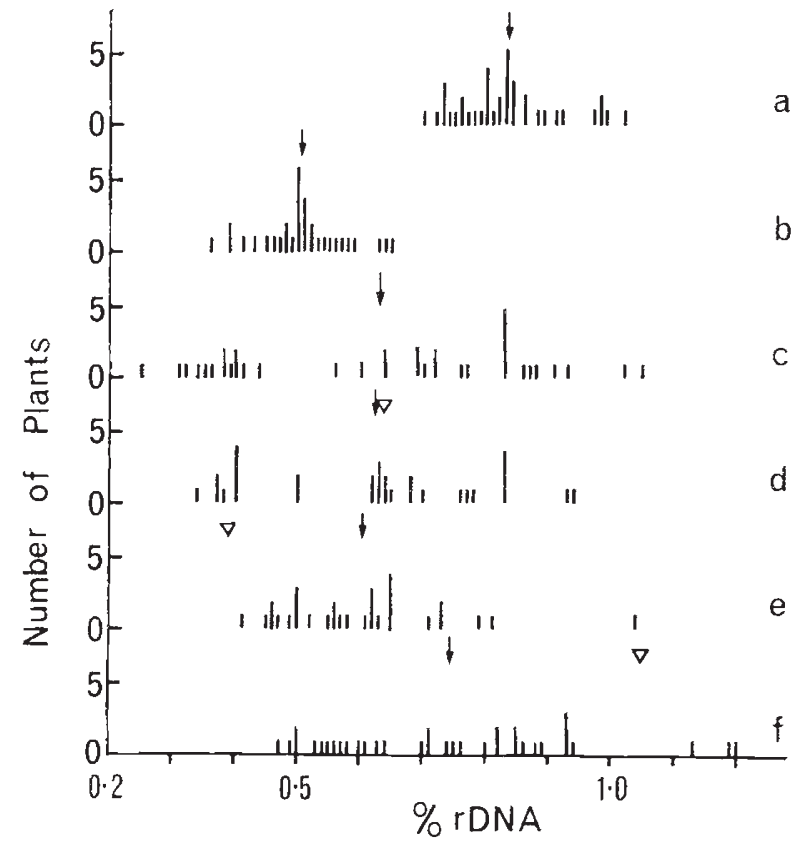

FIG. 1.-Proportion of rDNA of single plants of $\mathrm{L}$ and $\mathrm{S}$ genotrophs and $\mathrm{F} I$ and $\mathrm{F} 2$ plants from a cross between L and S. Mean of distribution $(\downarrow)$. Value of FI plant from which F2 plants were grown $(\nabla)$. (a) L, (b) S, (c) FI, (d)-, (f) F2.

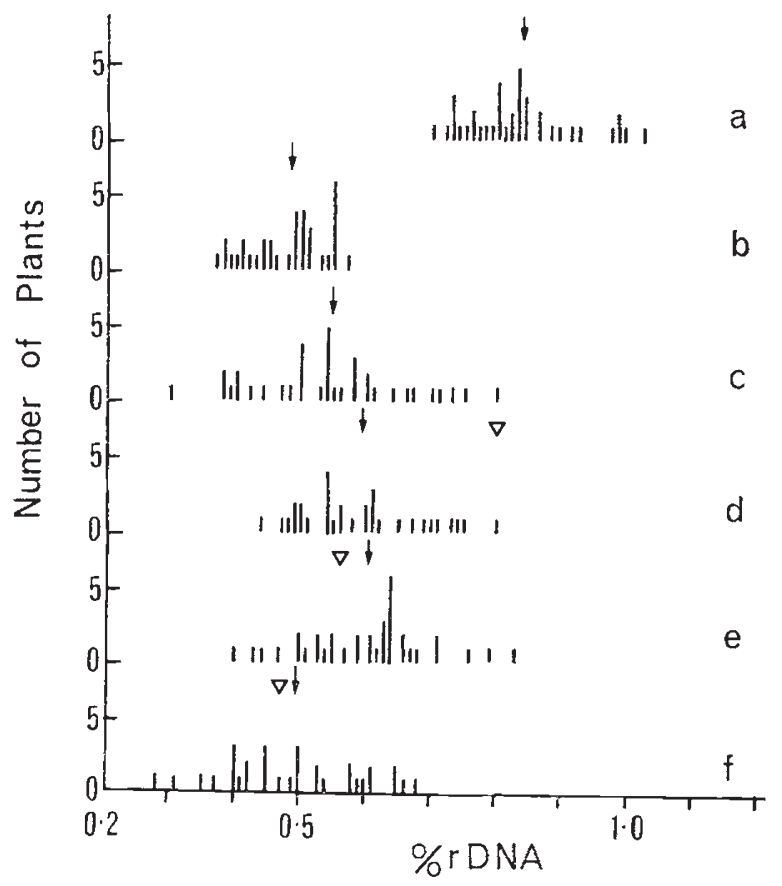

Fig. 2.-Proportion of rDNA of single plants of $L$ and $L_{6}$ genotrophs and $F 1$ and $F 2$ plants from a cross between $\mathrm{L}_{\text {and }} \mathrm{L}_{6}$. (a) $\mathrm{L}$, (b) $\mathrm{L}_{6}$, (c) FI, (d) -, (f) F2. Symbols as for fig. l. 
and 2. There was wide variation observed for all three genotrophs, but that of $\mathrm{L}_{6}$ was less than for either $\mathrm{L}$ or $\mathrm{S}$. The mean values for the $\mathrm{L}$ and $\mathrm{S}$ genotrophs were similar to the values previously obtained for DNA extracted from the leaves of a number of plants (Cullis, 1976), while the mean value for $\mathrm{L}_{6}$ was greater than that previously obtained.

The extent of the variation due to the experimental technique was determined by making at least two independent DNA preparations from a number of single plants, and by using different $r$ RNA preparations to hybridise to the same DNA preparation. For all three genotrophs used here, the variation between plants was significantly greater than that obtained from the replicate determinations on DNA from a single plant. The values are shown in tables 1 and 2 .

The rDNA of 10 plants, grown from seed collected from single plants of $\mathrm{L}$ and $\mathrm{S}$ with differing proportions of $\mathrm{rDNA}$, was determined and the results shown in table 3 . It can be seen that there is a high correlation between the proportion of rDNA of the parental plant and the mean value for each family. The low line within the $\mathrm{L}$ group had significantly less rDNA than the other three lines. The lower of the two $\mathrm{S}$ lines was significantly lower than the mean of the $S$ family shown in fig. $1 b$. Thus there is variation in the proportion of rDNA within a genotroph and it is possible to select lines from a single inbred plant which differ significantly for rDNA.

\section{(ii) $r D N A$ inheritance in a cross between $L$ and $S$}

One plant of each of $\mathrm{L}$ and $\mathrm{S}$ was selected and reciprocal crosses made between them. The proportion of rDNA was determined for DNA of single plants and the results are shown in fig. lc. The data from the reciprocal crosses have been pooled as no significant differences in either the means or variance were observed between them. The variation in the per cent rDNA was greater than that observed in either parent, the range of values extending beyond that observed in either of the parental lines. Therefore in the Fl there were changes in the proportion of rDNA, and any changes must have occurred in somatic cells.

\section{TABLE 1}

rDNA proportion determined for independent DNA preparations from single $L$ and $S$ plants

Per cent rDNA in DNA preparations*

Source of DNA

L
L
L
L
L
S
S
S
S
S

\begin{tabular}{ccc}
\hline 1 & 2 & 3 \\
0.83 & 0.82 & - \\
0.85 & 0.90 & - \\
0.82 & 0.87 & 0.80 \\
0.72 & 0.78 & - \\
0.72 & 0.74 & - \\
0.65 & 0.61 & - \\
0.61 & 0.67 & - \\
0.46 & 0.48 & 0.44 \\
0.51 & 0.55 & - \\
0.66 & 0.59 & -
\end{tabular}

* Hybridisation reactions carried out using the same rRNA preparation for each set of DNA preparations from a single plant. 
TABLE 2

$r D \mathcal{N} A$ proportion of single DNA preparations determined using different $r R \mathcal{N} A$ preparations

\begin{tabular}{|c|c|c|c|c|}
\hline \multirow[b]{2}{*}{ Source of DNA } & \multicolumn{4}{|c|}{ Per cent rDNA using rRNA preparation } \\
\hline & 1 & 2 & 3 & 4 \\
\hline $\mathrm{L}$ & 0.76 & - & 0.74 & - \\
\hline $\mathrm{L}$ & 0.94 & 0.91 & $\ldots$ & - \\
\hline $\mathrm{L}$ & 0.76 & $0 \cdot 70$ & - & - \\
\hline $\mathrm{L}$ & 0.82 & 0.87 & - & 一 \\
\hline $\mathrm{L}$ & - & - & 0.78 & 0.66 \\
\hline $\mathrm{I}$ & - & - & 0.81 & $0 \cdot 82$ \\
\hline $\mathrm{S}$ & 0.54 & 0.58 & - & - \\
\hline $\mathrm{S}$ & 0.54 & 0.59 & - & - \\
\hline $\mathrm{S}$ & 0.60 & 0.57 & - & - \\
\hline $\mathrm{L}_{6}$ & 0.46 & 0.48 & - & - \\
\hline $\mathrm{L} \times \mathrm{S} \mathrm{F} 1$ & - & - & 0.43 & $0 \cdot 42$ \\
\hline $\mathrm{L} \times \mathrm{S} F 1$ & $1 \cdot 10$ & - & 1.01 & - \\
\hline $\mathrm{L} \times \mathrm{S} F \mathrm{~F}$ & - & - & 0.96 & 0.84 \\
\hline $\mathrm{L} \times \mathrm{L}_{6} \mathrm{Fl}$ & - & - & $0 \cdot 60$ & 0.62 \\
\hline $\mathrm{L} \times \mathrm{L}_{6} \mathrm{~F} 1$ & - & - & 0.53 & 0.56 \\
\hline $\mathrm{L} \times \mathrm{L}_{6} \mathrm{Fl}$ & - & - & 0.60 & 0.66 \\
\hline $\mathrm{L} \times \mathrm{L}_{6} \mathrm{~F} 1$ & - & - & $0 \cdot 61$ & 0.52 \\
\hline $\mathrm{L} \times \mathrm{S}$ F2 & 0.74 & 0.63 & - & - \\
\hline $\mathrm{L} \times \mathrm{S}$ F2 & 0.61 & 0.65 & - & $0 \cdot 61$ \\
\hline $\mathrm{L} \times \mathrm{L}_{6} \mathrm{~F} 2$ & 0.78 & 0.68 & - & - \\
\hline $\mathrm{L} \times \mathrm{L}_{\mathrm{B}} \mathrm{F} 2$ & 0.74 & 0.73 & - & - \\
\hline $\mathrm{L} \times \mathrm{L}_{6} \mathrm{~F} 2$ & 0.61 & 0.56 & $\ldots$ & - \\
\hline $\mathrm{L} \times \mathrm{L}_{6} \mathrm{~F} 2$ & 0.44 & 0.53 & - & - \\
\hline $\mathrm{L} \times \mathrm{L}_{6} \mathrm{~F} 2$ & 0.52 & 0.49 & - & - \\
\hline $\mathrm{L} \times \mathrm{L}_{6} \mathrm{~F} 2$ & 0.38 & $0 \cdot 40$ & - & - \\
\hline
\end{tabular}

TABLE 3

Proportion of $r D N A$ in particular $L$ and $S$ plants and the mean values of the determination on 10 individual progeny from each

$\begin{array}{ccc}\text { Genotroph } & \text { rDNA }(\%) & \text { Progeny mean } \pm \text { S.E.M. (\%) } \\ \text { L } & 0.87 & 0.96 \pm 0 \cdot 10 \\ \text { L } & 0.98 & 0.98 \pm 0.12 \\ \text { L } & 0.70 & 0.68 \pm 0.06 \\ \text { L } & 0.99 & 0.92 \pm 0 \cdot 11 \\ \text { S } & 0.39 & 0.38 \pm 0.06 \\ \text { S } & 0.47 & 0.44 \pm 0.06\end{array}$

Three families of F2 plants were grown from seed of individual F1 plants with differing proportions of rDNA. The rDNA determinations on the DNA from the individual F2 plants are shown in fig. $1 \mathrm{~d}-\mathrm{f}$. It can be seen that in all three $\mathrm{F} 2$ families there was a wide range of values. The mean values of the $\mathrm{F} 2$ families were more similar to each other than were the values of the respective $\mathrm{Fl}$ plants from which they had been derived. This is in contrast to the observation with the $\mathrm{L}$ and $\mathrm{S}$ lines, where there was a high correlation between the value of the parental plant and the family mean of the offspring.

F3 plants were grown from six F2 plants and the rDNA determined for 10 individual F3 plants in each family. The means of the F3 families and 
the F2 parental values are given in table 4. The data show that there is no significant correlation between the F3 family means and the F2 value, although one family from an F2 plant with a high value gave a high family mean (this family had a higher rDNA amount than even the highest family mean obtained from $\mathrm{L}$ in this series of experiments). In five of the six F3 families the mean values were less different from the $\frac{1}{2}(L+S)$ value than the values of the F2 plants selected. This trend had also been observed in the F2 families.

Thus there would appear to be wide variation generated in the rDNA in the Fl plants of a cross between $\mathrm{L}$ and $\mathrm{S}$. The variation within a family obtained from a single $\mathrm{F} 1$ or $\mathrm{F} 2$ plant remains large, but the mean about

TABLE 4

Proportion of rDNA in particular F2 plants and the mean value of 10 individual F3 plants derived from each

$\begin{array}{ccc}\begin{array}{c}\text { Parents in } \\ \text { original cross }\end{array} & \text { F2 rDNA (\%) } & \text { F3 progeny mean } \pm \text { S.E.M. (\%) } \\ \text { L, S } & 0 \cdot 32 & 0 \cdot 62 \pm 0 \cdot 07 \\ \text { L, S } & 0 \cdot 35 & 0 \cdot 59 \pm 0 \cdot 12 \\ \text { L, S } & 0 \cdot 37 & 0 \cdot 81 \pm 0 \cdot 24 \\ \text { L, S } & 1 \cdot 03 & 1 \cdot 12 \pm 0 \cdot 25 \\ \text { L, S } & 1 \cdot 20 & 0 \cdot 59 \pm 0 \cdot 13 \\ \text { L, S } & 1 \cdot 13 & 0 \cdot 65 \pm 0 \cdot 25 \\ \text { L, L } & 0 \cdot 35 & 0 \cdot 51 \pm 0 \cdot 13 \\ \text { L, L } & 0 \cdot 37 & 0 \cdot 52 \pm 0 \cdot 12\end{array}$

which the values are spread tends to the mid-parent value of the two lines involved in the cross, rather than being closely correlated with the value of the plant from which the family is derived.

\section{(iii) $r D \mathcal{N} A$ inheritance in a cross between $L$ and $L_{6}$}

The cross between $\mathrm{L}$ and $\mathrm{L}_{6}$ was made (using the same $\mathrm{L}$ plant as that used in the cross between $\mathrm{L}$ and $\mathrm{S}$ ) and the proportion of rDNA in the progeny estimated as described for the cross between $\mathrm{L}$ and $\mathrm{S}$. Once again no reciprocal differences were observed so the data for the $\mathrm{Fl}$ values were pooled. The values for the rDNA of the Fl plants are shown in fig. 2c. The range of values is greater than expected and the mean of the F1 values less than the mid-parent value. No value was higher than expected from a combination of two parental plants having the highest rDNA values observed, but a number of values were lower than expected.

Three families of F2 plants were grown from individual F1 plants with different proportions of rDNA. The rDNA of individual F2 plants is shown in fig. 2 d-f. It can be seen that the F2 families show a similar variation to that observed in the F1 with the F2 family means being more similar to each other than the values of the respective plants from which they were derived. The F2 family means were all lower than the value of $\frac{1}{2}\left(L_{1}+L_{6}\right)$. For the family shown in fig. 2f, no F2 plant had a proportion of rDNA as high as the lowest value observed for L; that is no member of that F2 family would have been classified as $\mathrm{L}$ on rDNA alone.

Two families of F3 plants were grown from two of the low rDNA lines 
of the F2 family shown in fig. $2 \mathrm{f}$ and the rDNA of 10 individual plants determined. The means of these families are shown in table 4. It can be seen that the means were again approximately the same as the Fl mean and were not close to the value of the F2 plant from which they were derived.

The results obtained from the two crosses show both similarities and differences. In both crosses there is a wider range of rDNA values than expected in the F1. In subsequent generations the family means tended to be more similar to the mean of the two lines used in the cross than to the value of the plant from which they were derived.

The results of the two crosses differed from one another in the extent of the variation in the $\mathrm{Fl}$ and subsequent generations, and in the distribution of the means of the families. The variation in $\mathrm{L} \times \mathrm{L}_{6}$ was less than that in $\mathrm{L} \times \mathrm{S}$ in both the $\mathrm{F} 1$ and $\mathrm{F} 2$ generations. The mean of the mean values of the rDNA amount in the F1, F2 and F3 families in $\mathrm{L} \times \mathrm{L}_{6}(0.545$ per cent $)$ was the same as the Fl mean ( 0.545 per cent) and nearer the value for $\mathrm{L}_{6}(0.484$ per cent $)$ than the mean of the values of $\mathrm{L}$ and $\mathrm{L}_{6}(0.66$ per cent $)$. The mean of the mean values of the $\mathrm{Fl}$ and subsequent generations families for $\mathrm{L} \times \mathrm{S}(0.696$ per cent) was close to the mean of the values of $\mathrm{L}$ and $\mathrm{S}$ $(0.672$ per cent $)$.

\section{Discussion}

The number of ribosomal genes per nucleolar organiser has been shown to vary in many plant species, including flax (Cullis, 1976), Zea mays, (Phillips, Wang, Weber and Kleese, 1973), Pisum sativum (Cullis and Davies, 1975), wheat (Flavell and Smith, 1974; Liang, Wang and Phillips, 1977), hyacinth (Timmis, Sinclair and Ingle, 1972) and Allium cepa (Maggini, Barsanti and Marazia, 1978). The results for the three flax genotrophs reported here show that rDNA variations can occur within the progeny of a single inbred plant. The genotrophs involved in this study all have a history of instability. Flax and linseed lines not susceptible to environmental induction have not been studied and it remains to be seen whether they would show similar variation in rDNA amount between generations of a given inbred line.

Not only did the proportion of rDNA vary between generations, but the values obtained for the $\mathrm{Fl}$ plants showed that variation could occur within a generation and that the amount of variation observed was not necessarily the same in all lines. The variation in the $\mathrm{Fl}$ of the cross between $\mathrm{L}$ and $\mathrm{S}$ was greater than that for the cross between $\mathrm{L}_{\text {and }} \mathrm{L}_{6}$. Thus the extent of the variation, and the mean about which the values were distributed, was dependent on the particular genotrophs involved. In Drosophila melanogaster where rDNA variation has been observed, the extent of the variation, and even whether any change occurred at all, was dependent on the particular genotypes involved (Zuchowski and Harford, 1977).

The pattern of segregation in crosses between genotrophs of plant weight (Durrant and Tyson, 1964), capsule septa hair number (Durrant and Nicholas, 1970) and acid phosphatase isozyme band pattern (Cullis, 1979) cannot be explained on a simple Mendelian model. In the case of plant weight, the $\mathrm{F}_{1}$ of crosses between $\mathrm{L}$ and $\mathrm{S}$ show an immediate breakdown of stability and a range of plant weights is observed. In the $F_{2}$ there is a positive correlation between the weights of the $F_{1}$ plants and the $F_{2}$ family means (Durrant and Tyson, 1964). Variation in the capsule septa hair 
number occurs in the $F_{1}, F_{2}$ and $F_{3}$ generations of a cross between $L$ and $S$ (Durrant and Nicholas, 1970). The acid phosphatase isozyme band pattern shows dominance for the $L$ pattern in the $F_{1}$ in crosses between $L$ and $S$ and $L$ and $L_{6}$, but the segregation observed in the $F_{2}$ cannot be explained on a simple Mendelian model (Gullis, 1979). The peroxidase isozyme band pattern is the first character, which is susceptible to environmental induction, whose segregation in crosses between genotrophs can be explained on a simple Mendelian model (Cullis, 1979).

The question arises as to the mechanism by which the changes in the rDNA occurred, and whether the same mechanisms were responsible for both the changes observed within the genotrophs and those in the crosses. Two possible mechanisms for changing the number of ribosomal cistrons are unequal crossing-over (meiotic and/or mitotic) and the increase/loss of extrachromosomal copies. Both these mechanisms have been proposed to explain rDNA changes in Drosophila melanogaster. Unequal crossing-over has been proposed by Tartof (1974) to explain the occurrence of " rDNA compensation". In this case the compensation was a somatic event which occurred during the ontogeny of a single generation. Meiotic unequal crossing-over at the rRNA locus has also been proposed as a source of quantitative genetic variation in the same organism (Frankham, Briscoe and Nurthen, 1978).

Extrachromosomal copies of rDNA have been proposed to occur during the magnification of the bobbed locus (Ritossa, 1972). In certain combinations of $\mathrm{X}$ chromosomes, extrachromosomal copies of the rDNA have been shown in diploid somatic cells in Drosophila melanogaster (Zuchowski and Harford, 1977). Whether any of these mechanisms occurs in flax cannot be determined from the data presented here. However, a model of the environmental induction of heritable changes has been proposed (Cullis, 1977) in which DNA changes occur via an extrachromosomal intermediate, and the rDNA variation reported here may take place by the same mechanism. The rDNA of the genotrophs and crosses is being examined to determine whether extrachromosomal copies do occur.

The ribosomal genes account for only a small portion of the DNA involved in the induction of heritable differences in flax where differences between lines can be up to 16 per cent of the total DNA. The function(s) of the remainder of the DNA involved is not known and therefore not as amenable to analysis as the rDNA. Thus an understanding of the mechanisms behind the rDNA variation is being sought to provide a possible model for the basis of the changes in the remainder of the DNA involved.

Acknowledgements. - I am grateful to Dr A. Durrant for samples of seed of the three geno'rophs, and to Miss L. CharIton for her excellent technical assistance.

\section{REFERENGES}

BRowN, D. D., AND WEBER, C. s. 1968. Gene linkage by RNA-DNA hybridisation. I. Unique DNA sequences homologous to 4S, 5S and rRNAs. F. Molec. Biol., 34, 661-680. cullis, C. A. 1975. Environmentally induced DNA differences in flax. In Modification of the Information Content of Plant Cells, eds. R. Markham, D. R. Davies, D. A. Hopwood, and R. W. Horne, pp 27-36. North Holland, Amsterdam.

CULLIS, c. A. 1976. Environmentally induced changes in ribosomal RNA cistron number in flax. Heredity, 36, 73-79. 
CULLLIs, C. A. 1977. Molecular aspects of the environmental induction of heritable changes in flax. Heredity, 38, 129-154.

CULlis, C. A. 1979. Segregation of the isozymes of flax genotrophs. Biochem. Genet. (in press).

CUll.IS, C. A., AND DAVIES, D. R. 1975. Ribosomal DNA amounts in Pisum sativum. Genetics, $81,485-492$.

CULLIS, C. A., AND KOLODYNSKA, K. 1975. Variations in the isozymes of flax genotrophs. Biochem. Genet., 13, 687-697.

DURRANT, A. 1962a. The environmental induction of heritable changes in Linum. Heredity, $17,27-61$.

DURRANT, A. 1962b. Induction, reversion and epitrophism in flax. Nature, 196, 1302-1304.

DURRANT, A. 1971. The induction and growth of flax genotrophs. Heredity, 27, 277-298.

DURRANT, A., AND JONES, T. W. A. 1971. Reversion of the induced changes in amount of DNA in Linum. Heredity, 27, 431-439.

DURRANT, A., AND NICHOLAS, D. B. 1970. An unstable gene in flax. Heredity, 25, 515-522.

DURRANT, A., AND TYSON, H. 1964. A diallel cross of genotypes and genotrophs of Linum. Heredity, 19, 207-227.

EVANS, G. M., DURRANT, A., AND REES, H. 1966. Associated nuclear changes in the induction of flax genotrophs. Nature, 212, 697-699.

FLAVELL, R. B., AND SMITH, D. B. 1974. Variation in the nucleolar organiser rRNA-gene multiplicity in wheat and rye. Chromosoma (Berl.) , 47, 247-253.

FRANKHAM, R., BRISCOE, D. A., AND NURTHEN, R. K. 1978. Unequal crossing over at the rRNA locus as a source of quantitative genetic variation. Nature, 272, 80-81.

JOARDER, I. O., AL-SAHEAL, Y., BEGUM, J., AND DURRANT, A. 1975. Environments inducing changes in amount of DNA in flax. Heredity, 34, 247-253.

LIANG, G. H., WANG, A. S., AND PHILLIPS, R. L. 1977. Control of ribosomal RNA gene multiplicity in wheat. Can. F. Genet. Cytol., 19, 425-435.

MCLELLAN, J. C., AND DURRANT, A. 1973. Instability of Hh heterozygotes in flax genotrophs. Heredity, 30, 63-71.

MAGGINI, F., BARSANTI, P., AND MARAZIA, T. 1978. Individual variation of the nucleolus organiser regions in Allium cepa and A. sativum. Chromosoma (Berl.), 66, 173-183.

PHILLIPS, R. L., WANG, S. S., WEBER, D. J., AND KLEESE, R. A. 1973. The nucleolus organiser region (NOR) of maize. Genetics, 74, Suppl. 2, 212.

RItossa, F. 1972. Procedure for magnification of lethal deletions of genes for ribosomal RNA. Nature New Biology, 240, 109-111.

TARTOF, k. 1974. Unequal mitotic sister chromatid exchange as the mechanism of ribosomal RNA gene magnification. Proc. Natl. Acad. Sci. U.S., 71, 1272-1276.

TIMMIS, J. N., AND INGLE, J. 1973. Environmentally induced changes in rRNA gene redundancy. Nature New Biology, 244, 235-236.

TIMMIS, J. N., AND INGLE, J. 1975. The status of ribosomal RNA genes during nuclear DNA reversion in flax. Biochem. Genet., 13, 629-634.

timmis, J. N., sinclair, J., AND INGLE, J. 1972. Ribosomal RNA genes in euploids and aneuploids of hyacinth. Cell Differentiation, 1, 335-339.

zUCHOWSKI, C. I., AND HARFORD, A. G. 1977. Chromosomal rearrangements which affect the chromosomal integration of the ribosomal genes in Drosophila melanogaster. Cell, 11, 383-388. 